学術・技術論文

\title{
マイクロドームシステムによる直観的遠隔操作
}

\author{
佐 野 明 人*1 藤 本 英 雄 ${ }^{* 1}$ 梶 野 英 紀 $* 2$
}

\section{Intuitive Teleoperation through Micro Dome System}

\author{
Akihito Sano*1, Hideo Fujimoto*1 and Hidenori Kajino*2
}

\begin{abstract}
Master-slave system takes advantage of human cognitive and sensorimotor skills. However, in conventional system, the operator's visual and haptic frames of reference are widely separated. This lack of registration of sensory information causes a mental burden and contributes to a long learning curve in acquiring skills. Therefore, an intuitive teleoperation based on a natural and instinctive manner is strongly desired. In this study, keeping medical applications in mind, the master console with a compact spherical stereoscopic display, named Micro Dome, is developed and the accurate visual/haptic registration is realized based on the framework of a mixed reality. The operator looks like a fortuneteller viewing a crystal ball and can use his full set of daily experiences. The validity of proposed system is demonstrated by experiments of teleoperation.
\end{abstract}

Key Words: Master-Slave System, Visual/Haptic Registration, Intuitive Teleoperation, Spherical Stereoscopic Display, Mixed Reality, Medical Application

\section{1.はじめに}

現在, 遠隔手術支援ロボットの開発は, その重要性と社会に 与えるインパクトから本格的に推進されている [1]. 医療現場で は，あくまでも医師が手術の重要な担い手となる．遠隔システ ムの中で，マスタスレーブ方式は操作者の動作指令に従うこと が基本である。したがって，これは遠隔外科手術を支援する医師 主体のシステムとして有効である。もちろん，異スケール環境 下での作業にも適している. 最近, 米国 Intuitive Surgical 社の 開発したdaVinci が, 画期的な手術支援システムとして実際に 臨床応用され話題を呼んでいる [2]. このシステムの技術的背景 には，かつて SRI で開発された Telepresense Surgery System がある [3].

これまでの手術支援システムでは, 映像情報を提示するディ スプレイは，比較的見やすい位置に置かれるものの，手元の操 作系とは離れた位置 (オフセット) にあり，そのずれを操作者自 らが補正し操作を行う必要があった。しかしそれでもなお，触っ ている場所を見ていても，その場所からは実際の触っている感 覚は得られないといった視覚, 体性感覚情報の矛盾が生じてし まう。したがって，このような視覚系と力覚系 (操作系) が空 間上一致していない状況では，操作性を損なうばかりでなく大

原稿受付 2001 年 7 月 30 日

*1名古屋工業大学

*2 卜ヨ夕自動車 (株)

${ }^{* 1}$ Nagoya Institute of Technology

*2 Toyota Motor Corporation
きな精神的負担を強いられるものであり，さらにスキル習得に 時間を要し，獲得したスキルがこれ以外に活かせない可能性も ある。ここで, 空間上の一致を図ることをレジストレーション (Registration) と呼ぶ.この問題は重要であるにもかかわらず, これまで詳細な議論があまりなされてこなかった。

DaVinci では, ミラーを使った光学的重ね合わせで, 操作卓 に座った術者の手指に手術サイトの映像を投影し, EndoWrist と呼ばれるマニピュレータ先端部の直観的な操作を可能として いる [2]. また，術者用コンソールに顔を埋める形で中を覗き込 む没入型の操作環境が提供されている。また，一般的な微細作 業の分野では, Sato ら [4]が，力の高応答性を目的として開発 したペン形のマスタマニピュレータを，水平に置かれた平面ディ スプレイに直接押し当て, 映し出された対象を操作している．人 間の微細作業スタイルに注目し，直接的な操作インタフェース を構築した先駆的な研究である。一方，バーチャルリアリティの 分野では，視覚系および力覚系の正確なレジストレーションに ついて活発に議論がなされている [5] [6]. 例えば，横小路ら [5] は, WYSIWYF (What You can See Is What You can Feel) ディスプレイを提案している.

今後, 正確なレジストレーションを実現するインタフェース あるいはデバイスの検討, 開発がますます重要となる，HMD は, 重量, 拘束感, 視野角, 着脱の煩雑さ, さらに映像の提示部 位などの観点から，数時間に及ぶ手術などでは現実的ではない． また, Immersive Projection Technology を使ったプロジェク ション型没入ディスプレイ[7] は, スクリーンで取り囲んだ構 造となっており，装置全体が大きくならざるを得ないといった 
構造上の問題がある。手術支援システムのインタフェースとし ては, 既存の手術室への導入の観点から，コンパクト性や可搬 性が要求される。 また, 手術などの微細作業は, 基本的に操作 対象を周りから眺めることが多い[8].プロジェクション型没入 ディスプレイでは，デジタルモックアップなどの応用例がこれ に当たる。しかし，このような場合，必ずしも仮想世界の中に 身を置くような没入感は必要ないのではと考えられる。

本研究では，医療応用を念頭に置いた微細作業を支援する遠 隔操作システムの開発を目的とする。本論文では，手元で行う 作業に適したインタフェースを独自に開発し, 人間の自然な作 業動作に則した直観的操作が可能な新しい操作環境を提案する。 2 章では, 本研究で考えている直観的遠隔操作系について, その 基本コンセプトと特徵を示し, 球面立体視ディスプレイを核と したマスタコンソールについて述べる。3 章では，頭部運動を 考慮した立体映像提示に関して，実装方法を示した上で，モデ ルならびに関係式の導出について詳細に述べる。4章では，実 際に提示された立体映像をもとに，視覚／力覚のレジストレー ションに関して考察を行う。 5 章では, 操作性の観点から, 提 案する直観的遠隔操作システムの有効性を実験的に検証する.

\section{2. マイクロドームを介した遠隔操作環境}

\section{1 直観的遠隔操作系}

Fig. 1(a)に一つの日常的な操作環境を小す。奔板あたりまえ のことであるが，操作対象とそれが置かれている環境を直観的 に理解でき，見たものを触ることができる。本研究では，この ような環境, 操作スタイルを理想状態とする遠隔操作系を構築 する。具体的には, Fig. 1 (b) に示すように、ローカルの現実世: 界の一部にリモートの実世界（一種の仮想世界）を(拡大）再 現し，その仮想世界と向かい合う形での操作スタイルを考える.

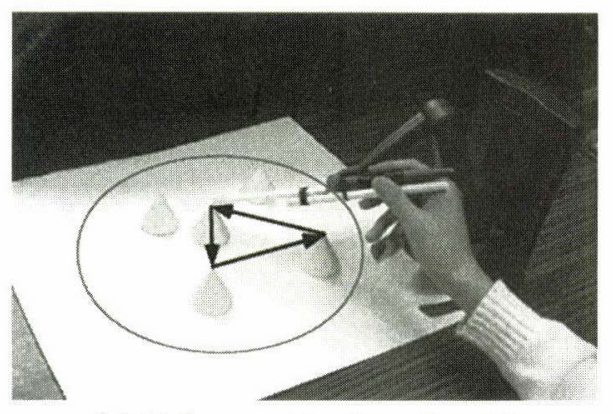

(a) Daily operation in real world

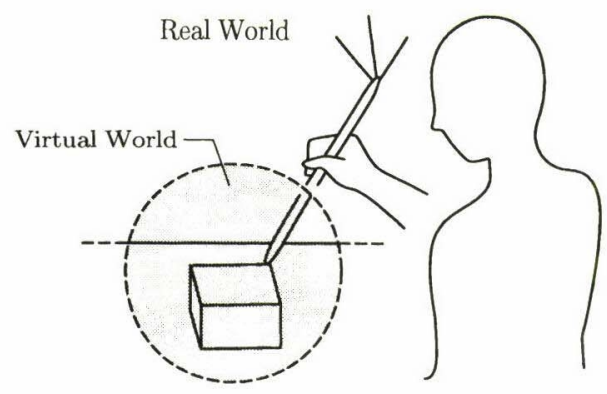

(b) Teleoperation based on mixed reality

Fig. 1 Intuitive teleoperation
さらに，現実と仮想の世界を視覚／力覚の観点からシームレ スにつなぐ複合現実感 (Mixed Reality) を実現する [9].すな わち，操作者が直接握っているグリップ (マスタッール) と仮想 世界内に見える先端部（スレーブッール）が，一つのッールと して認識, 操作できるようにする。このとき, 操作者は遠隔操 作（作業）をしているという意識を持つ必要がなく, Fig. 1 (a) に近い直観的な操作が可能となる.

\section{2 マスタコンソール}

Fig. 2(a)に開発したマスタコンソールとそれに正対した立位 姿勢の操作者を示す。ちょうど水晶玉を嗄き込む占師のような スタイルである、マスタコンソールは, 半球ドーム状の球面ディ スプレイ（マイクロドームと名付けた）内に操作環境を立体提 示する [10]. 提示可能な映像は, CG で構築した仮想世界（シ ミュレーション・訓練用) 拈よび実世界のライブ映像（遠隔操 作用) である. Satoらのシステムに対して, 本システムは対象 物を回り达んで眺めるような動作が，頭部運動を考慮した立体 映像提示により可能となり，コらに平面ではなく球面スクリー ンであることから連続的な提示が可能となる。これにより，操 作性の向上が期待できる。

ディスプレイに関しては, ホログラフィや龟山ら [11]の開発 した空間走査型ディスプレイが，三次元画像を生成し自然な立 体視を提供する。しかし，ホログラフィはリアルタイムでの表

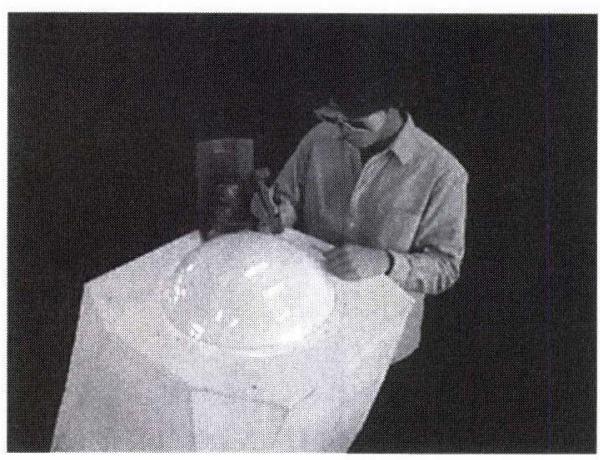

(a) Master console and operation style

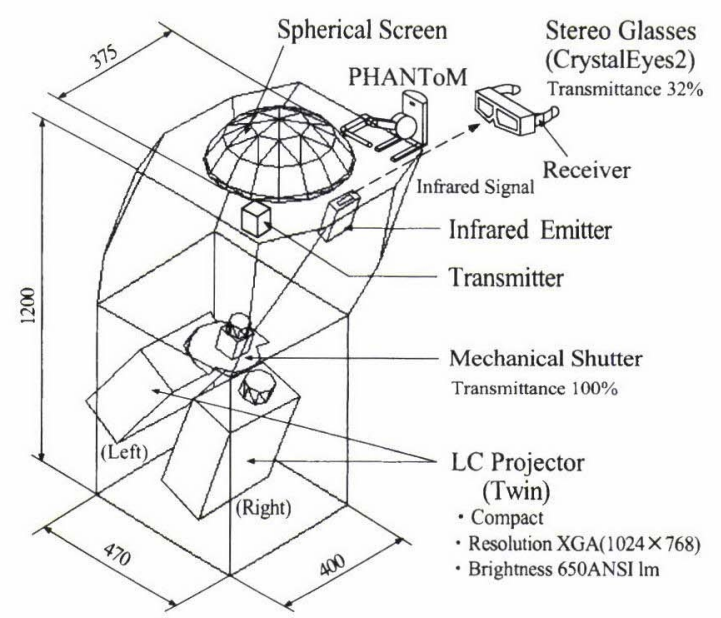

(b) Spherical stereoscopic display of rear-projection type

Fig. 2 Micro dome system 


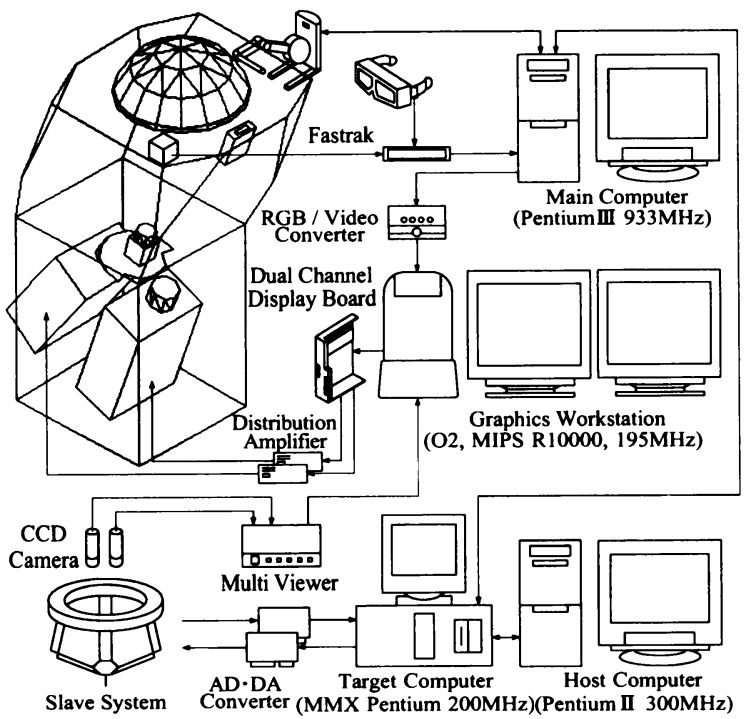

Fig. 3 System configuration

示が困難であり，空間走査型は低解像度である，そこで，本研 究では, バーチャルリアリティの分野で重要な技術として普及 している，両眼視差を利用した立体映像提示方式（2 眼式）を 採用する。ただし，三次元画像における自然な立体視に近づけ るために，対象を連続的に見たい位置・方向から捉えられるよ うに，頭部運動を考慮した球面スクリーンにおける立体映像提 示を行う。

マイクロドーム用に試作した背面投射型球面ディスプレイ を Fig. 2 (b) に示す。本システムでは，入手が容易でコンパク 卜な液晶プロジェクタ（EPSON，ELP-7100）による背面投射 $(\mathrm{XGA} ： 1,024 \times 768 ）$ を採用した。時分割方式による立体視 を実現するために，立体視に必要な左右眼用の画像を 2 台の液 晶プロジェクタで独立に投影し，プロジェクタ前面に配置した メカニカルシャッタと液晶シャッタ式メガネ (Stereo Graphics, CrystalEyes2）との同期を図る.すなわち，各プロジェク夕は 常に投影を行い，メカニカルシャッタを介して左右の映像が球面 スクリーン上に交互に表示される．また，頭部の位置·姿勢計測 用に磁気センサ（Polhemus Inc., Fastrak）を用いる. Fastrak のトランスミッタをドーム左脇に固定し，レシーバを液晶メガ ネの左サイドに固定した。

操作系として, マスタデバイス (SensAble Technologies, PHANToM Desktop）をドーム右脇に配置した．本研究では， 手術器具などを想定したツールを使った操作を想定している。 操作者が握っている PHANToM のグリップ $(15[\mathrm{~cm}])$ の先に 仮想のッール先端部 $(\phi 1 \times 16[\mathrm{~cm}])$ を取り付けた形になってい る (Fig. 1 (a) 参照). PHANToM では, ペン型グリップの先 端ジンバル部に絶対座標系で定義された 3 軸力が発生可能であ る。また，力覚提示に関しては，ライブラリGHOSTを用いる。 GHOST は, 幾何オブジェクトと空間効果の階層的集合体とし て, haptic 環境を表現する C++オブジェクト指向ッールキッ トである.また，力覚提示と視覚提示の処理を別のスレッドに 分けて並列に実行する．特に，力覚提示の処理を $1[\mathrm{kHz}]$ の周 期で呼び出す機能を提供する。

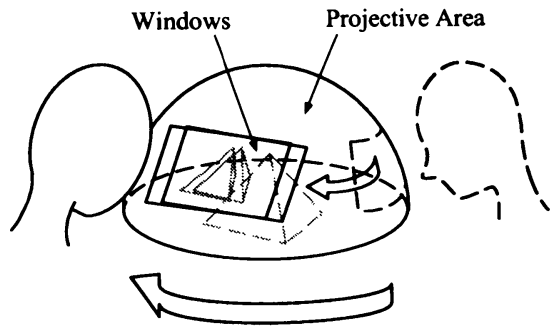

Fig. 4 Window control based on head tracking

Fig. 3 にシステム構成図を示す，全体システムとしては，分 散システムを構築した。トレーニング用の仮想環境系と遠隔操 作用の実環境系を有している。.OpenGL を使った仮想環境の構 築, 頭部の位置・姿勢計測および PHANToM の制御などには, Windows NT が稼㗢する PC (Pentium III, $933[\mathrm{MHz}]$ )を用 いる。一方, 3 章で述べる立体映像提示処理にはグラフィック ワークステーション O2（MIPS R10000, $195[\mathrm{MHz}]$ ）を使用 する，PC 上で生成した仮想世界の左右画像（1フレーム）は, RGB /ビデオ信号変換器（I・O DATA, TVC-XGA）を介し て, $\mathrm{O} 2$ のビデオ入力端子から取り込む. 一方, 2 台の $\mathrm{CCD}$ 力 メラ（ELMO，UN411）によって撮影された実映像は，2チャ ンネルのビデオ信号としてマルチビューワ（朋栄, MV-10D）に 送られて，1チャンネルのビデオ信号に圧縮された後 $\mathrm{O} 2$ に取 り込む。ここで，O2にはデュアルチャネル・ディスプレイ・オ プションボードが搭載されており，作業領域 $(1,024 \times 768)$ が 2 倍に拡張されたことで 2 台のプロジェク夕に接続されている.

\section{3. 頭部運動を考慮した立体映像提示}

\section{1 映像提示方式}

本研究では，Fig. 4 に示すように，球面スクリーン上の投影 エリア内に適当なサイズのウィンドウを開いて操作対象を観察 する．さらら，視点変更に合わせてこのウィンドウを移動させ る.すなわち，プロジェクタを機械的には旋回させていない．ま た，望ましい画角と処理速度の観点から $21.6 \times 16.2[\mathrm{~cm}]$ のサ イズのウィンドウを開くことにした，なお，通常の操作を行う 場合として,ドームからの距離が $10 \sim 50[\mathrm{~cm}]$, 左右 $90^{\circ}$ 程度, ほほ真上からの立体視が可能である.

さて, ウィンドウへの映像提示に関しては, OpenGLのテク スチャマッピングに基づく手法を用いる. 2.2 節で述べたように， 仮想環境，実環境のいずれもビデオ信号として O 2 内に取り込 まれる. その際, 左右の原画像 $($ 各 $512 \times 256$ [pixels]) はビデ オ・ライブラリおよび DM バッファの機能を用いて, OpenGL のテクスチャと互換性を持つ形式でメモリ上にストアされる。こ の原画像のテクスチャデー夕を格子状に縦横 11 分割した上で, それぞれの格子点に対応する点を求め, 隣接する 4 点ごとにテ クスチャをマッピングするためのポリゴンを形成する，さらに， これら形成されたポリゴンから成るウィンドウを, 拡張された O2 の左右の画像表示領域に描画し，分割した原画像を対応す るポリゴンにそれぞれマッピングすることで映像提示を行う.

ここで, 球面スクリーンへ投影することからポリゴンに対し て歪補正を施す必要がある。もちろん，特殊レンズなど光学系 


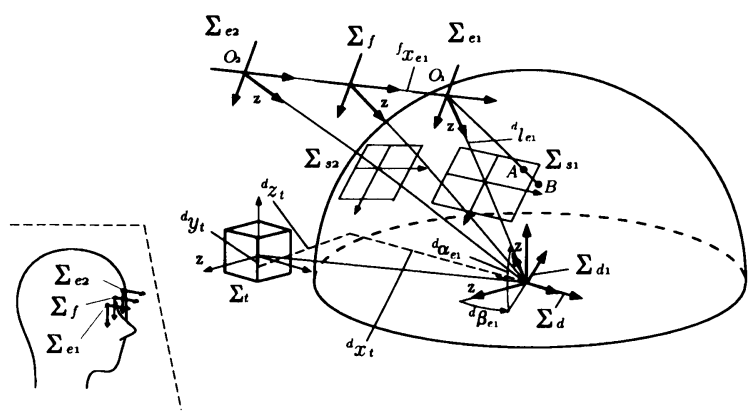

(a) Dome, face, viewpoint, transmitter and screen

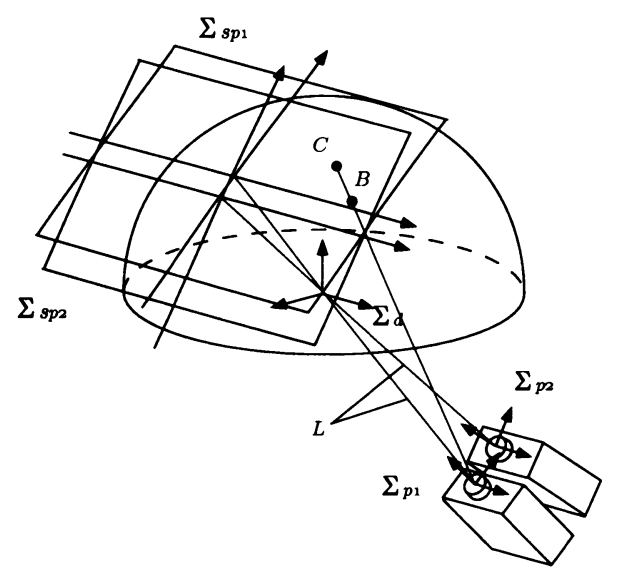

(b) Dome, projector and screen

Fig. 5 Model and coordinate frames

の設計を駆使することが考えられるが，ノウハウや開発コスト の点から容易なことではない，そこで, 本研究では, ソフトに よる歪補正を採用する．球面スクリーンに対して両眼視差を利 用した立体映像提示 (2 眼式)を行うために，次のような二つ の变換を考える必要がある。

（1）まず，左右眼用の原画像がドーム表面に設定した二つの仮 想スクリーンに見かけ上投影されているように，球面スク リーンに画像を実際に投影する (Fig.5(a) 参照).

(2)次に,この原画像に対応した画像が球面スクリーンに投影 されるように，ドーム表面に設定した二つのプロジェク夕 対応スクリーンに生成画像を見かけ上投影する（Fig. 5 (b) 参照).

具体的には，仮想スクリーン上のポリゴンを形成する格子点 $\mathrm{A}$ （視点座標系）に対応したドーム（球面スクリーン）上の点 $\mathrm{B}$

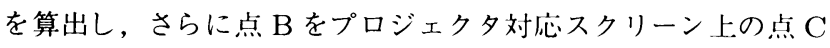
に変換する式を導出する。この変換を各格子点ごとに行うこと で，最終的に原画テクスチャをマッピングするポリゴンを算出 する．なお， 3.2 節および 3.3 節において，具体的な変換式を導 出する [12].

\section{2 視点パラメータ}

本研究では, Fig. 5 に示すようなドーム系，フェイス系，視 点系, プロジェク夕系およびスクリーン系などから構成される 座標系を設定した，各座標系は以下のと㧍り定義されている。

$\Sigma_{d}:$ ドーム座標系 (基準座標系)
Table 1 Values of parameters

\begin{tabular}{|c|c|c|c|c|}
\hline${ }^{d} x_{t}[\mathrm{~m}]$ & ${ }^{d} y_{t}[\mathrm{~m}]$ & ${ }^{d} z_{t}[\mathrm{~m}]$ & ${ }^{f} l_{e_{x}}[\mathrm{~m}]$ & - \\
\hline 0.204 & 0.099 & 0.215 & 0.031 & - \\
\hline \hline$r[\mathrm{~m}]$ & $L[\mathrm{~m}]$ & $H[\mathrm{~m}]$ & $\omega_{1}[\mathrm{deg}]$ & $\omega_{2}[\mathrm{deg}]$ \\
\hline 0.2 & 0.9 & 0.39 & 76.0 & 55.5 \\
\hline
\end{tabular}

$\Sigma_{f}:$ フェイス座標系

$\Sigma_{e_{i}}:$ フェイス座標系に固定され視点座標系

( $i=1,2: i=1$ は右眼, $i=2$ は左眼に対応)

$\Sigma_{d_{\imath}}:$ 視点座標系と連動するドーム座標系

$\Sigma_{s_{i}}:$ 仮想スクリーン座標系

$\Sigma_{p_{i}}:$ プロジェクタ座標系

$\Sigma_{s_{p_{i}}}:$ プロジェクタ対応スクリーン座標系

$\Sigma_{t}:$ トランスミッタ座標系

まず，簡単化のために， $\Sigma_{e_{i}}$ の $z$ 軸に固定された視線が常に ドーム中心に向かうものとする，次に， $\Sigma_{t}$ を介在させること で, $\Sigma_{d}$ から $\Sigma_{f} へ$ 同次変換行列 ${ }^{d} T_{f}$ は, 次のように導出で きる。

$$
{ }^{d} T_{f}={ }^{d} T_{t}{ }^{t} T_{f}
$$

ここで,

$$
\begin{aligned}
{ }^{d} T_{t}= & \operatorname{Trans}\left({ }^{d} x_{t},{ }^{d} y_{t},{ }^{d} z_{t}\right) \\
{ }^{t} T_{f}= & \operatorname{Trans}\left({ }^{t} x_{f},{ }^{t} y_{f},{ }^{t} z_{f}\right) \operatorname{Rot}\left(z,{ }^{t} \phi_{f}\right) \\
& \times \operatorname{Rot}\left(y,{ }^{t} \theta_{f}\right) \operatorname{Rot}\left(x,{ }^{t} \psi_{f}\right)
\end{aligned}
$$

ただし $,{ }^{d} x_{t},{ }^{d} y_{t}$ および ${ }^{d} z_{t}$ は, ドーム中心からのトランス ミッタのオフセット量である. 各パラメータの值を Table 1 に 示しておく.また, ${ }^{t} x_{f},{ }^{t} y_{f},{ }^{t} z_{f},{ }^{t} \phi_{f},{ }^{t} \theta_{f}$ および ${ }^{t} \psi_{f}$ は, $\Sigma_{t}$ 座標系に拐ける $\Sigma_{f}$ 座標系の位置・姿勢を表したものである.

次に, $\Sigma_{f}$ 座標系で記述された右眼座標は, ${ }^{d} T_{f}$ を導入する ことで $\Sigma_{d}$ 座標系で次のように表される。

$$
{ }^{d} \boldsymbol{X}_{e_{1}}={ }^{d} T_{f}^{f} X_{e_{1}}
$$

ここで,

$$
\begin{aligned}
{ }^{d} \boldsymbol{X}_{e_{1}} & =\left[\begin{array}{llll}
{ }^{d} x_{e_{1}} & { }^{d} y_{e_{1}} & { }^{d} z_{e_{1}} & 1
\end{array}\right]^{T} \\
{ }^{f} \boldsymbol{X}_{e_{1}} & =\left[\begin{array}{llll}
{ }^{f} l_{e_{x}} & 0 & 0 & 1
\end{array}\right]^{T}
\end{aligned}
$$

${ }^{f} l_{e_{x}}$ はフェイス座標系 $\Sigma_{f}$ からの眼のオフセットである. さら に, $\Sigma_{d}$ は極座標を採用しているので, ${ }^{d} \boldsymbol{X}_{e_{1}}$ から右眼の極座標 $\left({ }^{d} \alpha_{e_{1}},{ }^{d} \beta_{e_{1}},{ }^{d} l_{e_{1}}\right)$ が計算できる.

\section{3 映像提示式}

仮想スクリーン上の格子点 $A\left({ }^{e_{1}} x_{s_{1}},{ }^{e_{1}} y_{s_{1}},{ }^{d} l_{e_{1}}-r\right)$ は, ドー

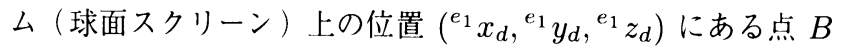
の像が, 次のような関係で透視投影されたものである.

$$
\left[\begin{array}{ll}
{ }^{e_{1}} x_{s_{1}} \\
{ }^{e_{1}} y_{s_{1}}
\end{array}\right]=\frac{{ }^{d} l_{e_{1}}-r}{{ }^{e_{1}} z_{d}}\left[\begin{array}{l}
{ }^{e_{1}} x_{d} \\
{ }^{e_{1}} y_{d}
\end{array}\right]
$$

ただし， $r$ はドーム半径である． $\Sigma_{d_{1}}$ 座標系で記述されたドー 厶上の点 $B$ を $\Sigma_{e_{1}}$ 座標系で表すと次のようになる。なお， $\Sigma_{d_{1}}$ は,ドーム中心を原点とし $z$ 軸が右眼方向となる座標系であり， 
$\Sigma_{d}$ を $y$ 軸周りに ${ }^{d} \beta_{e_{1}}, x$ 軸周りに $-{ }^{d} \alpha_{e_{1}}$ だけ回転した座標 系である。

$$
{ }^{e_{1}} \boldsymbol{X}_{d}={ }^{e_{1}} T_{d_{1}}{ }^{d_{1}} \boldsymbol{X}_{d}
$$

ここで,

$$
\begin{aligned}
{ }^{e_{1}} \boldsymbol{X}_{d} & =\left[\begin{array}{llll}
{ }^{{ }^{1}} x_{d} & { }^{e_{1}} y_{d} & { }^{e_{1}} z_{d} & 1
\end{array}\right]^{T} \\
{ }^{{ }_{1}} \boldsymbol{X}_{d} & =\left[\begin{array}{llll}
r \cos \phi \cos \theta & r \cos \phi \sin \theta & r \sin \phi & 1
\end{array}\right]^{T} \\
{ }^{e_{1}} T_{d_{1}} & =\operatorname{Trans}\left(0,0,{ }^{d} l_{e_{1}}\right) \operatorname{Rot}(x, \pi)
\end{aligned}
$$

${ }^{e_{1}} T_{d_{1}}$ は $\Sigma_{d_{1}}$ から $\Sigma_{e_{1}}$ への同次変換行列である.

これより，以下の式が得られる。

$$
\begin{aligned}
\tan \theta & =-\frac{{ }^{e_{1}} y_{s_{1}}}{{ }^{{ }_{1}} x_{s_{1}}} \\
\sin \phi & =\frac{{ }^{d} l_{e_{1}} d_{2}{ }^{2}+\left({ }^{d} l_{e_{1}}-r\right) \sqrt{r^{2} d_{1}{ }^{2}-{ }^{d} l_{e_{1}}{ }^{2} d_{2}{ }^{2}}}{r d_{1}{ }^{2}}
\end{aligned}
$$

ここで, $d_{1}=\sqrt{x_{s_{1}}{ }^{2}+y_{s_{1}}{ }^{2}+\left({ }^{d} l_{e_{1}}-r\right)^{2}}, \quad d_{2}=\sqrt{x_{s_{1}}{ }^{2}+y_{s_{1}}{ }^{2}}$ であり，それぞれ $\Sigma_{e_{1}}$ の原点あるいは $\Sigma_{s_{1}}$ の原点と $A$ 点間の 距離を表している。

次に,ドーム上の点 $B$ を $\Sigma_{p_{1}}$ 座標系で表すと次のように なる。

$$
{ }^{p_{1}} \boldsymbol{X}_{d}={ }^{p_{1}} T_{d_{1}}^{d_{1}} \boldsymbol{X}_{d}
$$

ここで

$$
\begin{aligned}
{ }^{p_{1}} \boldsymbol{X}_{d}= & {\left[\begin{array}{llll}
{ }^{p_{1}} x_{d} & { }^{p_{1}} y_{d} & { }^{p_{1}} z_{d} & 1
\end{array}\right]^{T} } \\
{ }^{{ }_{1}} T_{d_{1}}= & \operatorname{Trans}(0, d H, L-r) \operatorname{Rot}\left(x, \omega_{1}\right) \\
& \times \operatorname{Rot}\left(y,{ }^{d} \beta_{e_{1}}\right) \operatorname{Rot}\left(x,-{ }^{d} \alpha_{e_{1}}\right)
\end{aligned}
$$

${ }^{p_{1}} T_{d_{1}}$ は $\Sigma_{d_{1}}$ から $\Sigma_{p_{1}}$ への同次変換行列である。なお， $d H$ は， $H$ を投影画面の縦方向の長さとすると, $d H=H(L-r) / 2 L$ となる(投影方式による). $L$ は右眼用のプロジェクタと対応す る右スクリーン $p_{1}$ との距離である。また， $\omega_{1}$ は， $\Sigma_{d_{1}}$ と $\Sigma_{p_{1}}$ の $z$ 軸同士のなす角度である。

ドーム上の位置 $\left({ }^{p_{1}} x_{d},{ }^{p_{1}} y_{d},{ }^{p_{1}} z_{d}\right)$ にある点 $B$ の像は, 次のようにプロジェクタ対応スクリーン上の点に映る点 $C\left({ }^{p_{1}} x_{p_{1}},{ }^{p_{1}} y_{p_{1}}, L\right)$ に投影される.

$$
\left[\begin{array}{ll}
{ }^{p_{1}} x_{p_{1}} \\
{ }^{p_{1}} y_{p_{1}}
\end{array}\right]=\frac{L}{{ }^{p_{1}} z_{d}}\left[\begin{array}{l}
{ }^{p_{1}} x_{d} \\
{ }^{p_{1}} y_{d}
\end{array}\right]+\left[\begin{array}{c}
0 \\
-\frac{H}{2}
\end{array}\right]
$$

なお，左眼に関する定式化も同様に行われる.

$$
\text { 4.レジストレーション }
$$

4.1 視覚/カ覚のレジストレーション

Fig. 6 は，マイクロドームで実際に提示された映像を操作者 の視点からデジタルカメラにて撮影したものである. 左右眼用

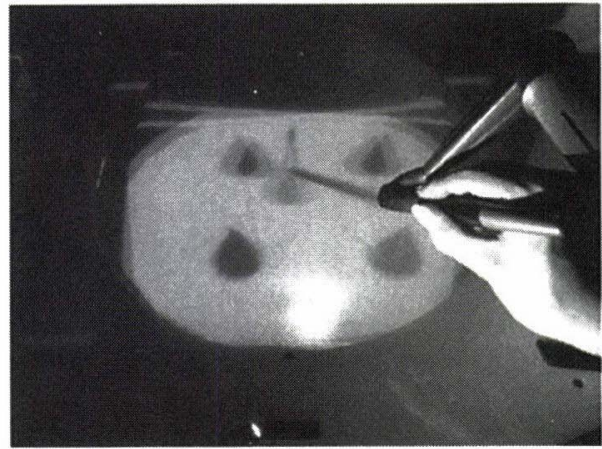

(a) CG cones and tool

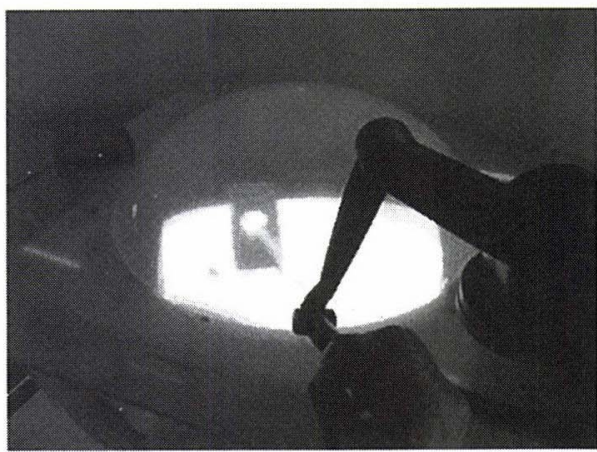

(b) CG box with hole

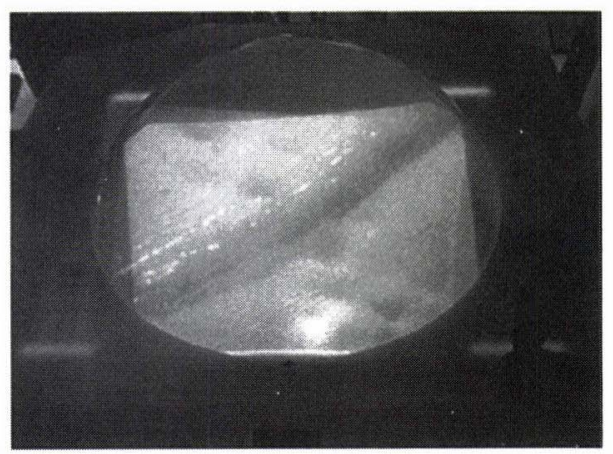

(c) Actual blood vessel

Fig. 6 Visual/haptic registration

の映像が提示されており，液晶シャッタ式メガネを掛けることで 立体視できる.Fig. 6 (a) は, Fig. 1 (a) と同じ五つのコーンを 仮想環境として構築したものである。また，Fig. 6 (b) は，仮想 環境内のボックスを正面から右側へ周って眺めていき，穴が直 視しやすい位置での映像である。さらに，Fig. 6 (c) は，2 $[\mathrm{mm}]$ 程の擬似血管を 2 台の CCD カメラでステレオ視し，拡大提示 したものである。

実験では，実際の投影画像を観察しながら，観察者が最も立 体的にはっきり見えるように，3章で示したモデルならびに変 換式の確認，物理パラメータの同定，メカニカルシャッタと液 晶シャッ夕式メガネとの同期調整などを行った。その結果, 観 察者にとって違和感のない立体映像の提示を実現した。ドーム を持ち上げるとそこに対象物が実際にあるのだと操作者に感じ させる。また，Fig.6(a) から分かるように，操作者が握ってい るツールグリップがドーム内のツール先端へとつながり，あた 


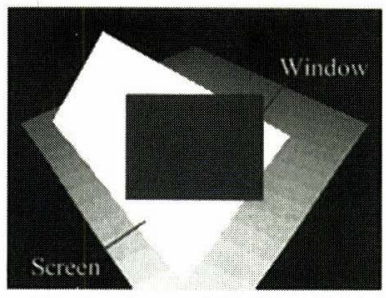

(a) Flat screen (flame out)

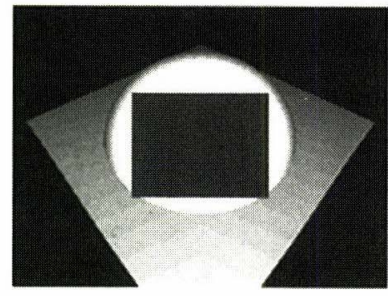

(b) Spherical screen

Fig. 7 Screen and window (viewpoint: 45[deg])

かも一つのッールのように感じられる。ささらら，中央のコーン に触った状態であり，見たものに触ることができる（四では反 カがベクトルとしても表示されている)，以上のことから，視覚 ノ力覚のレジストレーションが適切に図られている.

Fig. 6 (b)に示すように, 球面スクリーンでは連続的な表示面 を確保することができ，平面スクリーンを組み合わせた場合に 生じる映像の継ぎ目の問題が回避できる [13].したがって, 自然 な形で周囲から眺めることができ，その物体を一方向から捉え たときよりもリアリティが増した。ここで，マイクロドームの ような球面スクリーンと一般的な平面スクリーンに関して考察 しておく。まず，液晶シャッ夕式メガネによる立体視の多くは， CRT モニタのような平面ディスプレイでの利用が一般的であ り，あくまでも正面からの観察を前提としている。平面スクリー ン 1 面のみでは, 見る角度によりウィンドウがフレームアウト する。例えば，ドーム直径と同じ平面スクリーンを想定すると，

Fig. 7(a) に示すように，およそ $45^{\circ}$ の角度以上でフレームア ウトが生じる。この問題を回避するには，平面スクリーンを組 み合わせる必要がある。一方, 球面スクリーンでは, Fig. 7 (b) に示すように，フレームアウトを生じない.

\section{2 動的レジストレーション}

マスタッールである PHANToM の位置・姿勢計測のタイミ ングから最終的に表示系での描画が終了するまでの遅れ時間 (End-to-end system delay) が 0.1 [sec] 程度になっている.し

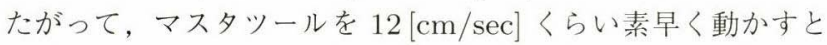
操作したマスタッールとドーム内のスレーブの映像のずれが生 じる.すなわち, 時系列上での一致が図られていない動的レジ ストレーションエラーが生じることになる [14]，そこで，本研 究では, 搪張カルマンフィル夕を用いた運動予測によりエラー 低隇を図る [15].

まず，仮想スレーブッールの位置・姿勢およびそれらの速度 で構成される十二次元ベクトルを状態变数ベクトル $\boldsymbol{x}_{k}$, また, 害際に計測されるスレーブの位置・姿勢で構成される六次元べ クトルを観測べクトル $\tilde{\boldsymbol{y}}_{k}$ とすると, 操作系の状態方程式 (離 散時間系）は，次のように導出される。

$$
\begin{aligned}
\boldsymbol{x}_{k+1} & =\boldsymbol{F} \boldsymbol{x}_{k}+\boldsymbol{G}\left(\boldsymbol{x}_{k}\right) \boldsymbol{w}_{p k} \\
\tilde{\boldsymbol{y}}_{k} & =\boldsymbol{H} \boldsymbol{x}_{k}+\boldsymbol{v}_{k}
\end{aligned}
$$

上式では，システムノイズ $\boldsymbol{w}_{p k}$ および観測ノイズ $\boldsymbol{v}_{k}$ を考慮 している.

ここで, 状態変数まわりで線形化することにより, 次式のよ うな搪張カルマンフィルタを得る。

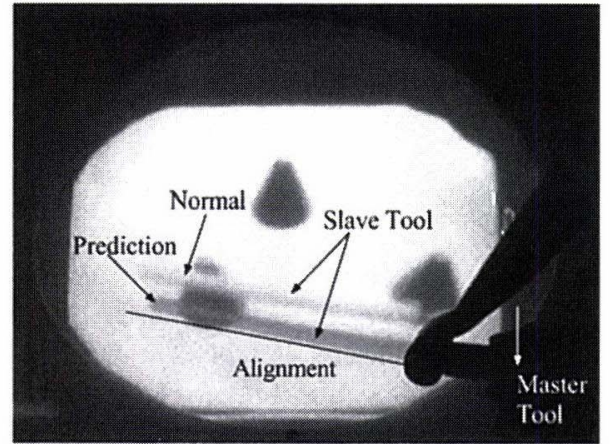

Fig. 8 Dynamic registration

$$
\begin{aligned}
\hat{\boldsymbol{x}}_{k \mid k} & =\hat{\boldsymbol{x}}_{k \mid k-1}+\boldsymbol{K}_{k}\left[\tilde{\boldsymbol{y}}_{k}-\boldsymbol{H}\left(\hat{\boldsymbol{x}}_{k \mid k-1}\right)\right] \\
\hat{\boldsymbol{x}}_{k+1 \mid k} & =\boldsymbol{F} \hat{\boldsymbol{x}}_{k \mid k} \\
\boldsymbol{K}_{k} & =\hat{\Sigma}_{k \mid k-1} \boldsymbol{H}^{T}\left(\boldsymbol{H} \hat{\Sigma}_{k \mid k-1} \boldsymbol{H}^{T}+\Sigma_{v k}\right)^{-1} \\
\hat{\Sigma}_{k \mid k} & =\hat{\Sigma}_{k \mid k-1}-\boldsymbol{K}_{k} \boldsymbol{H} \hat{\Sigma}_{k \mid k-1} \\
\hat{\Sigma}_{k+1 \mid k} & =\boldsymbol{F} \hat{\Sigma}_{k \mid k} \boldsymbol{F}^{T}+\hat{\boldsymbol{G}} \Sigma_{\boldsymbol{w}} \hat{\boldsymbol{G}}^{T}
\end{aligned}
$$

ただし， $\boldsymbol{G}$ は $\boldsymbol{G}\left(\hat{\boldsymbol{x}}_{k \mid k}\right)$ で定義される。また， $\boldsymbol{K}_{k}$ は離散時刻 $k$ におけるカルマンゲインであり， $\hat{\boldsymbol{x}}_{k \mid k}$ および $\hat{\boldsymbol{x}}_{k+1 \mid k}$ は, $\boldsymbol{x}_{k}$ の最適推定值， $\hat{\boldsymbol{x}}_{k \mid k}$ に基づく $\boldsymbol{x}_{k+1}$ の推定値である.ささらに， $\hat{\Sigma}_{k \mid k}, \hat{\Sigma}_{k+1 \mid k}, \Sigma_{w k}$ および $\Sigma_{v k}$ は共分散行列である.

実験では, 約 $8[\mathrm{~cm}]$ の幅を $1[\mathrm{~Hz}]$ 程度の周期でマスタッー ルを振ってみた。なお，推定値の更新周期は $0.08[\mathrm{sec}]$ とした。 Fig. 8 は，マスタッールを手前に動かした際の通常の描画と運 動予測に基づいた描画の両者を表示させたものである. 図から 分かるように，通常の描画では，表示されたスレーブッールが マスタッールに追従できていない。一方，運動予測に基づいた 描画では，マスタとスレーブが一直線に合うように映像提示さ れている.

\section{5. 操作性の検 証}

\section{1 評価技法}

本章では, 操作性の検証を行う [12]. 実験タスクとして次の 2 通りを考え，その実行時間を調べる。

タスク A タスクAでは, Fig. 1(a) に示すような実環境下 での操作を理想状態とし，提案したシステムを介した遠隔操作 が，どの程度の直観的な操作性を実現しているかを作業実行時 間により評価する。また，立体視掞よび視覚系と力覚系（操作 系）の空間上一致した状況が，操作性にどの程度関与している かを検証するために，五つのケースでの実験を行う。

Fig. 9 (a) に示すような，作業領域内に配置された四つのコー ンの各頂点を順に触っていく実験夕スクである（図中に軌跡の 一例が示してある)。コーンは, 下面の直径 $5[\mathrm{~cm}]$, 上面の直径 $1[\mathrm{~cm}]$, 高さ $5[\mathrm{~cm}]$ である。まず，本番とは異なる配置での練 習を行う，その後，中央のコーンからスタートするが，本番の コーンはスタートの合図とともに提示される。また，各頂点で は約 1 秒間保持するように指示してある。

Table 2 に示す五つの組み合わせで実験を行う。ここで, A-1 抄よび A-3のレジストレーションが取れていない場合は, PHAN- 


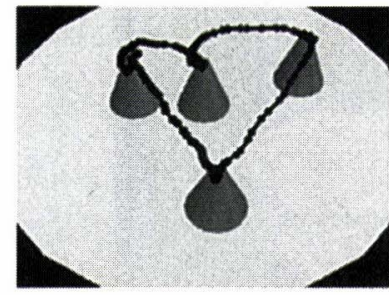

(a) Task A

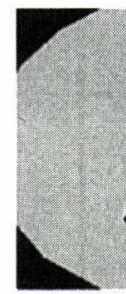

(b) Task B
Fig. 9 Experimental environment of tasks

Table 2 Experimental conditions

\begin{tabular}{|c|c|c|c|c|c|c|c|}
\hline & \multicolumn{5}{|c|}{ Task A (Touch) } & Task B (Insert) \\
\hline & 1 & 2 & 3 & 4 & 5 & 1 & 2 \\
\hline \hline Interface & \multicolumn{3}{|c|}{ Micro Dome } & - & Micro Dome \\
\hline Environment & \multicolumn{3}{|c|}{ Virtual } & Real & Virtual \\
\hline Registration & $\times$ & 0 & $\times$ & 0 & 0 & 0 \\
\hline Stereo & $\times$ & $\times$ & 0 & 0 & 0 & \\
\hline Viewpoint & \multicolumn{9}{|c|}{ Fix } & Variable \\
\hline
\end{tabular}

ToM が右側に $10[\mathrm{~cm}]$, 手前に $10[\mathrm{~cm}]$ だけオフセットしてい る。また，A-5の実環境とは, 球面スクリーンを外し，そこに まったく同じ模型の作業環境を配置したものである，さらに，操 作者には, Fig. 9 (a)に示すような形で環境が見える位置で姿勢 を保持し，頭部を動かさないで操作するように指示してある。

タスク B 人間は日常の経験から作業を的確に行うために視 点を適切に移動している, そこで, タスク Bでは, 頭部運動を 考慮した映像提示の有効性を検証する.

Fig. 9 (b)に示すような，斜め 45 にに配置されたボックスに 空けられた穴へッールを挿入し, 奥の面に当てる実験タスクで ある.ボックスは高さ $10[\mathrm{~cm}]$, 幅 $5[\mathrm{~cm}]$, 厚み $2[\mathrm{~cm}]$ であり, 穴は直径 $3[\mathrm{~cm}]$ である. 左下のスタートポイントから始め, 挿 入完了後再びスタートポイントに戻る。もし，穴以外の部分に 触れた場合はもう一度スタートポイントに戻りやり直す. 練習 は行わない。また, Table 2 に示す二つの組み合わせで実験を行 う。すなわち, Fig. 9(b)に示す正面の位置に視点が拘束されて いる場合と自由に変えられる場合である。

本実験では，多ク A，Bに対してそれぞれ成人男子 14 名 を被験者に選定し，すべての被験者にすべての実験パ夕ーンを 行わせる (Within-subject). タスク A は, A-1 から A-5の順 でまたタスク Bは，B-1，B-2の順で実験を行った，各実験で とに 7 回の試行データをサンプリングした。ここで, 人間を対 象とした評価実験では慣れが問題となり，同じ方法・環境では 後に行った実験ほどよい成績が記録される恐れがある [16].そ こで，各実験を 1 日ごとに実施することで慣れの影響を抑元た。

\section{2 実験結果と考察}

Fig. 10 は, 各実験でとの全被験者の実行時間の平均值と標 準偏差を示す。平均值を比較すると, A-1 から A-4の順で成績 が良くなっていることから，個人差はあるものの，タスク Aに は立体視が重要であり, 次いでレジストレーションが効果的で あることが分かる，立体視により，四つのコーンの位置関係が よく分かり, 対象とそれが置かれている環境を身体座標系で直 観的に理解できる。また，レジストレーションが取れていると， 4 章で示したように, マスタスレーブ系があたかも一つのッール

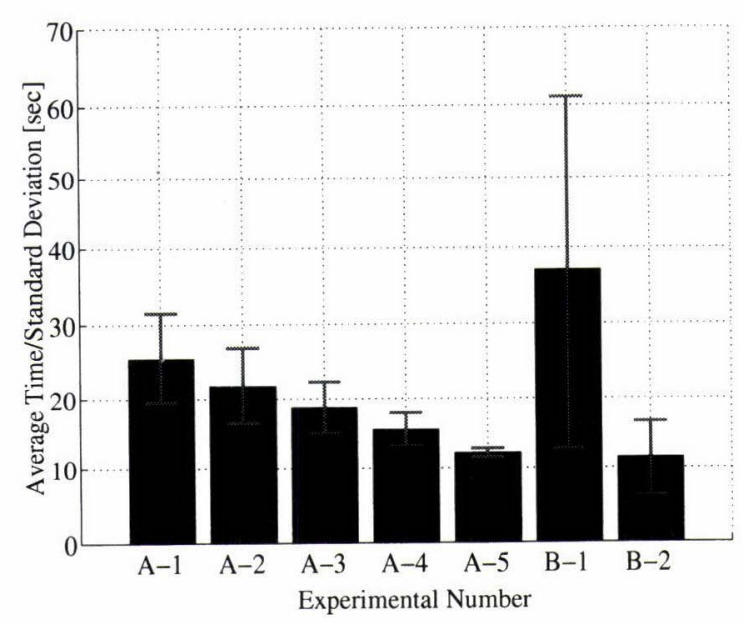

Fig. 10 Average time and standard deviation

のように感じられ，さらに見たものに触ることができる。した がって, 操作者にとっては日常の経験に則した直観的なッール 操作が可能となる。このことは, A-4 と A-5の比較から, 提案 するシステムが実環境下での操作に近いレベルを達成している ことからもいえる。また, 標準偏差を比較すると, 同じく A-1 から A-4 の順で小さくなっており, 操作にばらつきが生じず安 定してタスクが実行できている.

B-1 と B-2 の比較から, 視点変更を許すことで, 各被験者ご とに適切な位置へ視点を移し (Fig. 6 (b) 参照), 確実に挿入で きるパスを選んだ上で, 的確に挿入作業を行っている。したがっ て, 失敗の回数が減り実行時間ならびに標準偏差ともに大幅に 小さくなっている，さらに，このとき，継ぎ目のない連続的な 表示の有効性が実感できる。このことから, 頭部運動を考慮し た球面スクリーンに扩ける立体映像提示が極めて有効であると いえる。
6. 結
論

本研究は, 医療応用を念頭に置いた遠隔微細作業システムの 開発を目的とし, 人間の自然な作業動作に則した直観的操作が 可能な新しい操作環境を構築した. 以下に本研究で得られた結 果をまとめる。

(1)球面立体視ディスプレイを核とした新しいインタフェース の開発を行った。球面スクリーンに対して両眼視差を利用 した立体映像提示 ( 2 眼式) を行うために, ポリゴンウィ ンドウに対して歪補正を施した。最終的に, 観察者にとっ て違和感のない立体映像提示を実現した。さうに, 視点座 標系で立体映像提示モデルを構築したことで, 対象を連続 的に見たい位置・方向から捉えられる. 特に, 自然な形で 周囲から眺めることができ, 物体を一方向から捉えたとき よりもリアリテイが増した。

(2)現実世界と仮想世界をドームを介して明確に分けているも のの, 視覚系と力覚系 (操作系) を空間上一致させ, 本来 独立したマスタとスレーブに対して両世界をつなぐ一つの ッールとしての動きを実現させた。これにより，見たもの に触ることができるといった視覚と体性感覚情報の合致を 
実現した。さらに拡張カルマンフィルタを用いた運動予測 により時系列上での動的整合性も実現した。

(3)操作者にとっては日常の経験に則した直観的なツール操作 が可能となった。 また, 操作にばらつきが生じず安定して タスクが実行できた。実感として実環境下での操作に近い といえる。さコに，視点变更を許すことで，与えられた夕 スクを的確に実行することが可能となった。

今後, NASA-TLX などの主観的作業負荷評価尺度を使った 負担軽減の評価，とっさのときに適切な対応を取ることができ るかなどの評価を定量的に行っていく予定である。ささらに，遠 隔地からの操作を含めた実環境への展開 [17], 微細作業におけ るスケーリング問題 [18] [19]. さらに仮想手術トレーニングの 観点から, 生体組織などの柔軟物の変形・操作の実現などが, 今 後の課題として挙げられる。

謝 辞 最後に，医療現場の立場からご助言頂きました名古 屋大学医学部形成外科の鳥居修平教授ならびに医局の方々に深 く感謝致します。また, 本研究は, 文部省科学研究費補助金平 成 8 年度奖励研究 $(\mathrm{A})$ （課題番号:08750312）および平成 10 年 度萌芽的研究 (課題番号:10875056) の援助を受けており，ここ に謝意を表する。

\section{参 考 文 献}

[1] 特集：21 世紀の医療とロボティクス，日本ロボット学会誌, vol.18, no. 1, pp. $1-52,2000$

[2] G.S. Guthart and J.K. Salisbury: "The Intuitive ${ }^{\text {TM }}$ Telesurgery System: Overview and Application," Proc. of the 2000 IEEE Int. Conf. on Robotics \& Automation, pp.618-621, 2000.

[ 3 ] P.S. Green, J.W. Hill, J.F. Jensen and A. Shah: "Telepresence Surgery," IEEE Engineering in Medicine and Biology Magazine, vol.14, no.3, pp.324-329, 1995.

[4] T. Sato, J. Ichikawa, M. Mitsuishi and Y. Hatamura: "Micro Teleoperation System Concentrating Visual and Force Information at Operator's Hand," Proc. of the 3rd Int. Symposium on Experimental Robotics, pp.353-365, 1993.

[5] 横小路泰義, ラルフホリス, 金出武雄：“仮想環境への視覚/力覚イ ンタフェース：WYSIWYF デイスプレイ”，日本バーチャルリアリ ティ学会論文誌, vol.2, no.2, pp.17-26, 1997 .

[6] 山田俊郎, 小木哲朗, 盇内大輔, 斎藤允, 広田光一, 廣瀬通孝：“触 力覚提示装置のための傾斜 3 面ディスプレイの開発”, 日本バーチャ ルリアリティ学会第 5 回大会論文集, pp.287-290, 2000.

[7] 特集：プロジェクション型没入ディスプレイ，日本バーチャルリアリ テイ学会論文誌, vol.4, no.3, pp.477-554, 1999.

[8] 光石衛, 渡辺拓郎, 中西泰文, 浅井亮介, 渡辺博義: “テレ・マイク ロ・サージェリ・システムの試み”，日本機械学会ロボティクス・メ カトロニクス講演論文集, vol.B, pp.1408-1411, 1995.

[9] 田村秀行：“複合現実：現実世界と仮想世界の融合”，日本ロボット学 会誌, vol.16, no.6, pp.759-762, 1998 .

[10] 佐野明人, 藤本英雄, 関谷友孝, 梶野英紀：“テレマイクロオペレー ションのためのマイクロドームシステムの開発”, 日本バーチャルリ アリテイ学会第 4 回大会論文集, pp.411-412, 1999.

[11］大富浩一，亀山研一：“VR 用三次元ディスプレイの開発”, PIXEL, no. 132 , pp. $54-56,1993$

[12] 佐野明人, 藤本英雄, 梶野英紀, 磯部立, 竹内博良：“マイクロドー ムシステムによる直感的遠隔操作”, 第 6 回ロボティクスシンポジア 予稿集, pp.81-86. 2001 .

[13] 岩田洋夫, 橋本渉：“背面投射球面ディスプレイ”, Human Interface N \& R, vol.12, no.2, pp.119-124, 1997.

[14] R.T. Azuma: "A Survey of Augmented Reality," Presence, vol.6, no. 4 , pp. 355-385, 1997

[15] 横小路泰義, 菅原嘉彦, 吉川恒夫：“画像と加速度計を用いた HMD 上での映像の正確な重ね合わせ”, 日本バーチャルリアリティ学会論 文誌, vol.4, no.4, pp.589-598, 1999

[16] 田村博 編：ヒューマンインタフェース。オーム社, pp.2-8, 1998

[17] 藤本英雄, 佐野明人, 岡本啓史: “インターネットを介した力帰還型バイ ラテラル遠隔操作”, 日本ロボット学会誌, vol.18, no.5, pp.713-720, 2000.

[18] A. Sano, H. Fujimoto, and T. Takai: "Network-Based Micro Teleoperation," Proc. of the Japan/USA Symposium on Flexible Automation, pp.13044(1)-(2), 2000.

[19] 藤本英雄, 山川聡子, 真鍋紳：“マスタースレーブに括ける弁別閾 を考虑した力のスケーリング”、日本ロボット学会誌, vol.19, no.3. pp.402-407. 2001

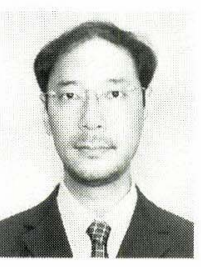

佐野明人 (Akihito Sano)

1963 年 2 月 8 日生. 1987 年 3 月岐阜大学大学院 工学研究科精密工学専攻修上課程修了. 現在, 名古 屋工業大学助教授. テレロボティクス, 人間一機械 系の研究に従事. 日本機械学会賞研究奨励賞受賞, 日本機械学会ロボティクス・メカトロニクス部門 賞 (業績賞) 受賞. 2000 年 Japan-USA Flexible Automation Symposium 最優秀論文賞受賞. 第 6 回ロボティクスシ ンポジア優秀論文賞受賞。2 $2001 \cdot 2002$ 年度本学会評議員。日本機械 学会, 計測自動制御学会, 日本バーチャルリアリティ学会等の会員. 博士 (工学).

(日本ロボット学会正会員)

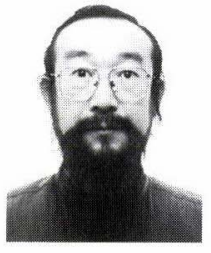

藤本英雄 (Hideo Fujimoto)

1947 年 7 月 7 日生. 1970 年名古屋大学工学部機械 工学科卒業. 現在, 名古屋工業大学教授、生産システ ム，ロボットなどの知能化，バーチャルリアリティ。 感性の工学などに興味を持つ. 2000 年 Japan-USA Flexible Automation Symposium 最優秀論文賞受 賞、第 6 回ロボティクスシンポジア優秀論文賞受賞. ASME 1998 Japan-USA Flexible Automation Symposium プロク ラム委員長. 1997, 1998 年 SICE 常務理事部門協議会議長. 1997, 1998 年日本機械学会評議員. 1991，1992 年本学会誌編集委員。工学 博上.
(日本ロボット学会正会員)

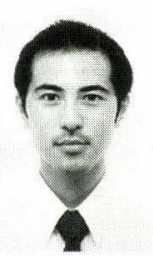

梶野英紀 (Hidenori Kajino)

1976 年 6 月 30 日生. 1999 年名古屋工業大学工学 部機械工学科卒業. 2001 年同大学大学院工学研究 科生産システム工学専攻博上前期課程修了。同年卜 ヨ夕自動車（株）人社. 